\title{
Anatomical poems
}

Cite as: CMAJ 2019 November 11;191:E1252-3. doi: 10.1503/cmaj.190769

\section{The birth of an Anatomical Venus "[The] Anatomical Venus ... was conceived as a means of teaching human anatomy ... this life-sized, dissectible wax woman ... can be disassembled into seven anatomically correct layers." - The Anatomical Venus by Joanna Ebenstein, 2016}

\section{First, death:}

hundreds of bodies for one slashed beauty. An artist renders the molds, shapes the heart, the lungs, the spleen. Fingers impress the clay.

Then, approval - a plaster cast, now choose the virgin wax and colour the pale marrow with toxic pigments.

Pour the wax into the molds.

Stuff her hollows with wood, rag, or wire; varnish the hair to her head. Insert the eyelashes, glaze her body for a reflective edge. Dress - or don't.

Recline her on a plush cushion and arrange a pose, a delicate hand to preserve her false modesty. Remove her breastplate, open to the public but only men of study.

Adorn her with pearls; from the sea, she will rise.

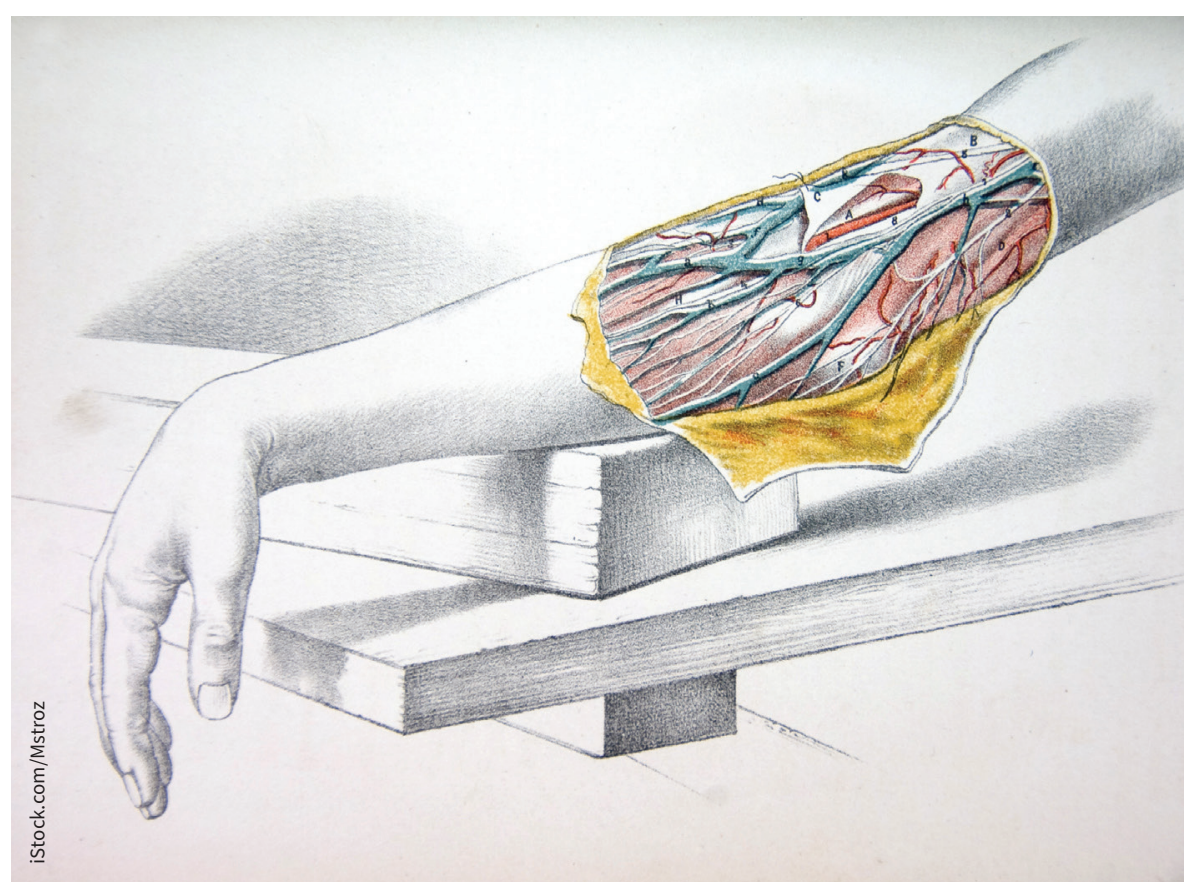

\section{Anatomical angel}

After L'Ange anatomique by JacquesFabien Gautier d'Agoty, 1746.

Your back is flayed open but you zip up your dress to hold in the skin.

What can you do

but keep moving?

Doctors prick you with needles and peel open your skin.

One finger moves your muscles aside and pokes a rib, the other plays percussion on your spine.
You wake in the morning and feel the ghosts of pain. Tendons snap as you stretch.

When you open your eyes, they bend over you again and ask you to twist to the side.

Each time meant to be the last you're back they hold their needles aloft and begin to sew. 


\section{Autopsy}

I have been opened and emptied, sliced from collarbone to breastbone, sawed through the sternum, scraped from the inside out.

My heart has been weighed and measured; someone has sliced around my scalp just below the hairline and peeled my skull to the bone.

My eyes watch from their sockets but my hands lie useless on the table, and my tongue is leaden in my mouth.

They've sawed open my skull, and I watch them poke at my brain.

Even if I knew what was wrong, they wouldn't discover it.

\section{The lady anatomist}

For Anna Morandi Manzolini

The Lady Anatomist is not here for your gaze; she is here to teach: she dips her scalpel, bears down on the saw.

Here, let me pull back the skin

to better display the brain.

She can unmake your body, and remake it entirely, or as part of the whole: here you are as an ear, an eye, a hand.

She looks on death, and takes her measurements, lifts her forceps, makes her notes. She heats the wax, colours it, and molds it to her specifications.

She will not lie on this table to be taken by feminine rapture; she will not settle for one string of pearls when she could have the whole colon.

She gave her child new life, and guided her husband to his grave. She will not take your false titles; she is no mother, no doctor, no saint.

She will not be shamed for her work, or praised. She alone touches the cadaver.

\section{She carries her death \\ For Anna Morandi Manzolini}

She carries her death into the cold room and lays it on the table next to today's cadaver.

Today's work is the hand, from the forearm to wrist, to joint, to knuckle, to finger, to nail.

Her scalpel focuses her eye, her hand, their hand; her fingers move, their fingers live.

This hand is scraped to the bone, these bones are the mold, this wax is the skin, this string is the vein.

But this wax carries another's fingerprints, a false blush, the nails indicate the scrape of tiny tools. Each detail impeccable.

This hand moves through space, its joints flex and finger the air.

Once this hand held a child's hand; once this hand held a dying woman's hand; once this hand held an apple, and poised it to bite.

This hand is her hand, but it is not her hand today.

This hand picks up her death from the table and carries it home.

\section{Courtney Bates-Hardy MA}

Regina, Sask.

These poems have been peer reviewed. 